\title{
Key pluvial parameters in assessing rainfall erosivity in the south-west development region, Romania
}

\author{
Monica Dumitraşcu ${ }^{1, *}$, Carmen-Sofia Dragotă ${ }^{1}$, Ines Grigorescu ${ }^{1}$, \\ Costin DumitraşCU ${ }^{2}$ and Alina Vlăduţ ${ }^{3}$ \\ ${ }^{1}$ Institute of Geography, Romanian Academy, 12 D. Racoviţă Street, Sect. 2, 023993 Bucharest, Romania. \\ ${ }^{2}$ Department of Geography, Spiru Haret University, 13 Ion Ghica Street, Sector 3, Bucharest, Romania. \\ ${ }^{3}$ Department of Geography, University of Craiova, 13 Al. I. Cuza Bvd, Craiova, Romania. \\ ${ }^{*}$ Corresponding author.e-mail: stefania_dumitrascu@yahoo.com
}

MS received 20 December 2016; revised 6 February 2017; accepted 7 February 2017; published online 19 June 2017

Located in the south-western part of Romania, the south-west development region overlaps the main relief forms: the Carpathians mountains, the Getic Subcarpathians, the Getic piedmont, the Romanian plain and the Danube valley. The study aims at providing an overview on the main pluvial parameters and their role in assessing rainfall erosivity in the study area. The authors assessed the occurrence, frequency and magnitude of some of the most significant pluvial parameters and their impact on the climatic aggressiveness in the study area. Thus, the monthly and annual mean and extreme climatic values for different rainfall related parameters (e.g., maximum amounts of precipitation/24 hr, heavy rainfall), as well as relevant indices and indicators for pluvial aggressiveness (Fournier, Fournier Modified, Angot) were calculated. The rainfall erosivity was assessed in order to provide both the spatial distribution of the triggering extreme weather phenomena and the resulted intensity classes for the analysed indices and indicators. The authors used long-term precipitation records (1961-2010) for the selected relevant meteorological stations distributed throughout all analysed relief units.

Keywords. Angot; Fournier; Fournier modified indices; rainfall aggressiveness; Romania; south-west development region.

\section{Introduction}

Soil erosion induced by water has triggered the interest of scientists and policy-makers in the last decades. According to Panagos et al. (2015), in Europe, soil erosion by water accounts for the greatest loss of soil compared to other erosion processes. Erosion rates are quite difficult to assess, especially at large scale, as there are numerous models, such as the one proposed by Morgan, based on scoring systems for different parameters, such as rainfall erosivity, soil erodability, slope and land use (Morgan et al. 1998), the empirical Universal
Soil Loss Equation (USLE) (Wischmeier and Smith 1978) and its revised version (RUSLE) (Renard et al. 1997), EMMED model (De Jong et al. 1998), etc. Beside soil type, topography, and land use, another important factor in estimating the rate of soil erosion by water is represented by rainfalls (total amounts and intensities). Thus, climatic factors, rainfall in particular, may lead to the intensification of the erosion processes especially when they register high intensities and occur immediately after a prolonged drought period.

In Romania, shifts between prolonged droughts and heavy rainfall that generated discontinuities 
in the multiannual range on larger surfaces determined changes in the frequency and intensity of extreme climate events (e.g., heavy precipitation and resulted floods, droughts and high temperatures) (Dragotă 2006; Busuioc et al. 2010). According to the World Health Organization (WHO 2013) and the Romanian Catastrophe Insurance Programme (PRAC), Romania is considered as highly exposed to natural disasters such as earthquakes, floods and landslides (Chendeş et al. 2015). Over the past years, precipitation extremes showed a widespread and significant increase, but the changes were less spatially coherent compared with the changes in temperature extremes (Busuioc et al. 2015).

However, important differences are recorded on regional scales (Busuioc et al. 2015), usually triggering significant flood events, most notably along the Danube in 2005, the Prut and the Siret rivers and over some of their tributaries in 2008 and 2010 (Ştefănescu et al. 2014).

Regularly, heavy precipitation associated with snow thawing can trigger floods, flash floods, changes in riverbeds, material damages and even casualties. As a result, water excess can cause slope instability, landslides or mudflows reactivation (Bălteanu 1997), soil degradation and shrinkage of agricultural productivity (Sandu et al. 2010). Consequently, in-depth studies on excess rainfall and other associated extreme weather events, e.g., unusual snow cover, positive thermal anomalies, hailstorms, wind intensification (Dragotă et al. 2014), are required.

\section{The study area}

The south-west development region is made up of five counties (Dolj, Gorj, Mehedinţi, Olt and Vâlcea) covering $12.3 \%$ of the Romanian territory and $10.7 \%$ of its population (2011). This region is located in the south-western part of Romania and overlaps the main relief forms from the heights of the Southern Carpathians and Banat mountains $(16.6 \%)$ in the north and north-west to the hills of the Getic Subcarpathians (11.0\%) and the Getic piedmont (41\%) in the centre and the Romanian plain (Oltenia plain subunit) and the Danube floodplain $(31.5 \%)$ in the south and south-west (figure 1). Thus, from north to south, the altitudes decrease from over $2500 \mathrm{~m}$ in the north-eastern part, in Parâng mountains (Parângul Mare Peak, $2518 \mathrm{~m}$ ) to $27 \mathrm{~m}$ in the Danube valley, east of the Jiu river. The south-west development region is delimited to the south and southwest by the Danube river, along the border with Bulgaria and Serbia.

The region falls into the temperate humid continental climate (Peel et al. 2007) which, under the stepwise display of all major relief forms and the complex interaction of different genetic factors (e.g., the dynamics of the air masses, the flux of solar radiation) has shaped the main climatic regions: plain, hill-tableland and mountain.

To these climatic regions, there are added climatic influences, which impose their own particular features: Mediterranean in the south-west bringing about hot summers, rainy autumns, and mild winters, oceanic in the north-west characterised by humid masses of air, rainfalls and west winds and transitional in the eastern extremity causing a slight decrease of precipitation (Bogdan and Niculescu 2006). Moreover, the climate is influenced by the landscape configuration (e.g., the Carpathian mountains in the north acting as an orographic barrier in the way of air masses, the relative altitudes, slopes exposure, vegetation, soils, water systems, man-made changes), thus shaping the main topoclimatic features. Of these, the most important are the foehn effects on the windsheltered southern mountain slopes, on those of Mehedinţi Plateau and Getic Subcarpathians triggered by the north and north-western circulation of air masses, as well as the mild or shelter climate felt in the sub-montane and intra-hilly depressions, valley corridors and Danube floodplain. Thus, landscape configuration determines a higher exposure to the pluvial climatic-related extreme events. Through their specific parameters (intensity, duration, quantity), in the study-area, precipitation extremes are dependent on altitude, relief, solar radiation, and on the role of orographic barrier played by the Carpathian mountains in the north and Pre-Balkan Plateau in the south (IonBordei 2008). Heavy rainfall may appear during summer when some specific conditions are overlapping: the predominant western air circulation, the highly active dynamics of the humid tropical air of Mediterranean origin or of polar-maritime air over Romania, and the unequal heating of the terrestrial surface. Generally, this triggers significant flood waves.

\section{Methodology and data}

Rainfall, through its characteristic parameters (duration, frequency and intensity), long-time 
occurrence and mechanical action, range among the key meteorological elements in unleashing land erosion processes (Dragotă et al. 2008). Thus, the current study is aimed at highlighting the significance of the selected pluvial indices in assessing precipitation conditions susceptible to affecting soil erosion in an area with various geographical conditions. In order to assess the pluvial hazards in the south-west development region, the main pluvial characteristics and the excess rainfall based on several indicators (e.g., maximum monthly precipitation amounts, maximum precipitation amounts fallen in short intervals) and indices (Fournier, Fournier Modified and Angot pluvial aggressiveness) were used. Consequently, the pluvial climatic hazards were assessed using a GIS-based methodology aiming to provide both the spatial distribution of the analysed extreme weather phenomena and the resulted intensity classes for the analysed indices and indicators. The above-mentioned computation was based on annual and monthly climatic values for the 1961-2010 time frame (provided by the National Meteorological Administration) from 15 meteorological stations spread throughout the study area.

The selection and the assemblage of the most representative weather stations was performed taking into account quantitative and qualitative criteria such as: altitude, configuration of the local relief, availability of homogenous rainfall data covering approximately the same period (1961-2010), etc. Thus, the grouping of three relevant weather stations for each of the five relief units of the studyarea resulted, covering altitudes of above $2000 \mathrm{~m}$ in the Southern Carpathians to less than $50 \mathrm{~m}$ in the Danube valley (table 1 ). The mediation of the rainfall parameters corresponding to each major relief unit represented the starting point for all indicators considered in the current research.

Rainfall erosivity can be assessed using several methods, of which, the most applicable is based on torrential rainfall intensity (Costea 2012) through several reference indices internationally renowned such as Angot (Fournier 1960) and Fournier modified (Arnoldus 1980). The selected indices were designed to differentiate and compare several relief units with specific geographical and climate features in order to monitor the temporal variation of the assigned parameters. Herewith, they have the benefit of relying on easy accessible input data (rainfall) and the quantification and ranking of their aggressiveness is made using already established value classes. Fournier index is generally applied when the density of the meteorological stations is reduced and the available rainfall data are scarce. Worldwide, the aforementioned indices were tested with notable results for different parts of Africa (Oduro-Afriyie 1996; Elagib 2010; Meshesha et al. 2015), Europe (Angulo-Martinez and Begueria 2009; Capra et al. 2015), South America (Munka et al. 2008), Asia (Elbasit et al. 2013; Yue et al. 2014; Mohtar et al. 2015), etc. In Romania, rainfall erosivity based on Fournier indices was determined for different parts of the country such as the Secaşul Mare basin (Costea 2012), Lipova Hills (Oncia and Copacean 2015) and eastern Romania (Stânga 2011). Studies focused on the relationship between Angot index and erosion processes were assessed for Muscle Basin (Buzău Subcarpathians) (Dragotă et al. 2008), Transylvanian plain (Rusu et al. 2014), Romanian plain (Grecu et al. 2011), and the Danube floodplain (Dragotă et al. 2014).

Fournier (FI) and Fournier modified (MFI) indices were calculated according to the following formula:

$$
\mathrm{FI}=\frac{\sum_{i=1}^{n}\left(p_{\max i}^{2} / P_{i}\right)}{n},
$$

where $p_{\max i}$ is the amount of water in the rainiest month of the year $(\mathrm{mm}) ; P_{i}$ is the annual rainfall amount (mm); and $n$ is the number of years of the observation period.

$$
\mathrm{MFI}=\frac{\sum_{i=1}^{12} p_{i}^{2}}{P}
$$

where $P_{i}$ is the monthly rainfall $(\mathrm{mm})$ and $P$ is the total annual rainfall ( $\mathrm{mm}$ ).

Based on these two indices, several susceptibility classes depending on the assigned rainfall parameters on each analysed relief unit were outlined (table 2).

Angot pluvial index $(K)$ was initially aimed at determining the characteristic types of monthly and annual variation of precipitation based on regional and local comparisons. It was computed according to the formula below (Dragotă et al. 2008):

$$
K=\frac{p}{P}
$$

where $p=q / n, q$ is the monthly precipitation amounts; and, $n$ is the number of days/months. 
Table 1. The selected weather stations on main relief units.

\begin{tabular}{|c|c|c|}
\hline Weather station & $\begin{array}{l}\text { Altitude } \\
\quad(\mathrm{m})\end{array}$ & Relief unit \\
\hline $\begin{array}{l}\text { Ţarcu } \\
\text { Obârşia Lotrului } \\
\text { Voineasa }\end{array}$ & $\left.\begin{array}{r}2180 \\
1348 \\
573\end{array}\right\}$ & $\begin{array}{l}\text { Southern Carpathians (including valley corridors and } \\
\text { intra-mountain depression areas) }\end{array}$ \\
\hline $\begin{array}{l}\text { Tg. Jiu } \\
\text { Rm. Vâlcea } \\
\text { Polovragi }\end{array}$ & $\left.\begin{array}{l}204 \\
242 \\
525\end{array}\right\}$ & $\begin{array}{l}\text { Getic Subcarpathians (including intra-hilly and sub- } \\
\text { mountain depressions) }\end{array}$ \\
\hline $\begin{array}{l}\text { Apa Neagră (Padeş) } \\
\text { Bâcleş } \\
\text { Tg. Logreşti }\end{array}$ & $\left.\begin{array}{l}260 \\
313 \\
271\end{array}\right\}$ & Getic piedmont \\
\hline $\begin{array}{l}\text { Caracal } \\
\text { Craiova } \\
\text { Băileşti }\end{array}$ & $\begin{array}{r}105 \\
192 \\
59\end{array}$ & Romanian plain (Oltenia plain) \\
\hline $\begin{array}{l}\text { Calafat } \\
\text { Bechet } \\
\text { Drobeta Turnu Severin }\end{array}$ & $\left.\begin{array}{l}61 \\
39 \\
77\end{array}\right\}$ & The Danube Valley \\
\hline
\end{tabular}

Table 2. The frequency of years (\%) on pluvial erodibility classes ( $\mathrm{mm}$ ) according to FI and MFI.

\begin{tabular}{lllllll}
\hline FI classes & Very low & Low & Moderate & Severe & Very severe & Extremely \\
& $(0-20)$ & $(21-40)$ & $(41-60)$ & $(61-80)$ & $(81-100)$ & severe $(>100)$ \\
MFI classes & Very low & Low & Moderate & Severe & Very severe & \\
& $(0-60)$ & $(61-90)$ & $(91-120)$ & $(121-160)$ & $(>160)$ & \\
\hline
\end{tabular}

Table 3. Susceptibility classes of precipitation liable to triggering soil erosion based on Angot pluvial index.

\begin{tabular}{llllll}
\hline Pluviometric attributes & Very dry & Dry & Normal & Rainy & Very rainy \\
Pluvial erodibility classes & Very low & Low & Moderate & Severe & Very severe \\
Angot index values $(K)$ & $<0.99$ & $1.00-1.49$ & $1.50-1.99$ & $2.00-2.49$ & $>2.50$ \\
\hline
\end{tabular}

Processed after Dragotă et al. (2008).

$$
P=\frac{Q}{365}
$$

$Q$ is the multiannual precipitation amounts.

The resulted index values were used to determine the rainy intervals by grouping them under the pluvial classes corresponding to the assigned rainfall attributes (table 2). Therewith, the pluvial peaks for each relief unit were highlighted (Dragotă et al. 2008) (table 3).

In order to explain the cumulative effect of the erosivity triggered by precipitation, Angot pluvial index was computed using the climate data registered at the following weather stations: Țarcu for the Southern Carpathians, Polovragi for the Getic Subcarpathians, Apa Neagră (Padeş) for the Getic piedmont, Craiova for the Romanian plain and Calafat for the Danube valley (figure 1).
The calculated indicators enabled us to highlight certain spatial differences of rainfall erosivity within the analysed region.

\section{Results and discussion}

\subsection{The pluvial potential of the south-west development region}

The mean annual precipitation amounts decrease from north to south, namely from the Southern Carpathians area to the Danube valley (from over 1000 to $400-500 \mathrm{~mm})$. The intermediary relief steps (hills and plateaus) represented by the Getic Subcarpathians and piedmont sums up 700-800 mm, 


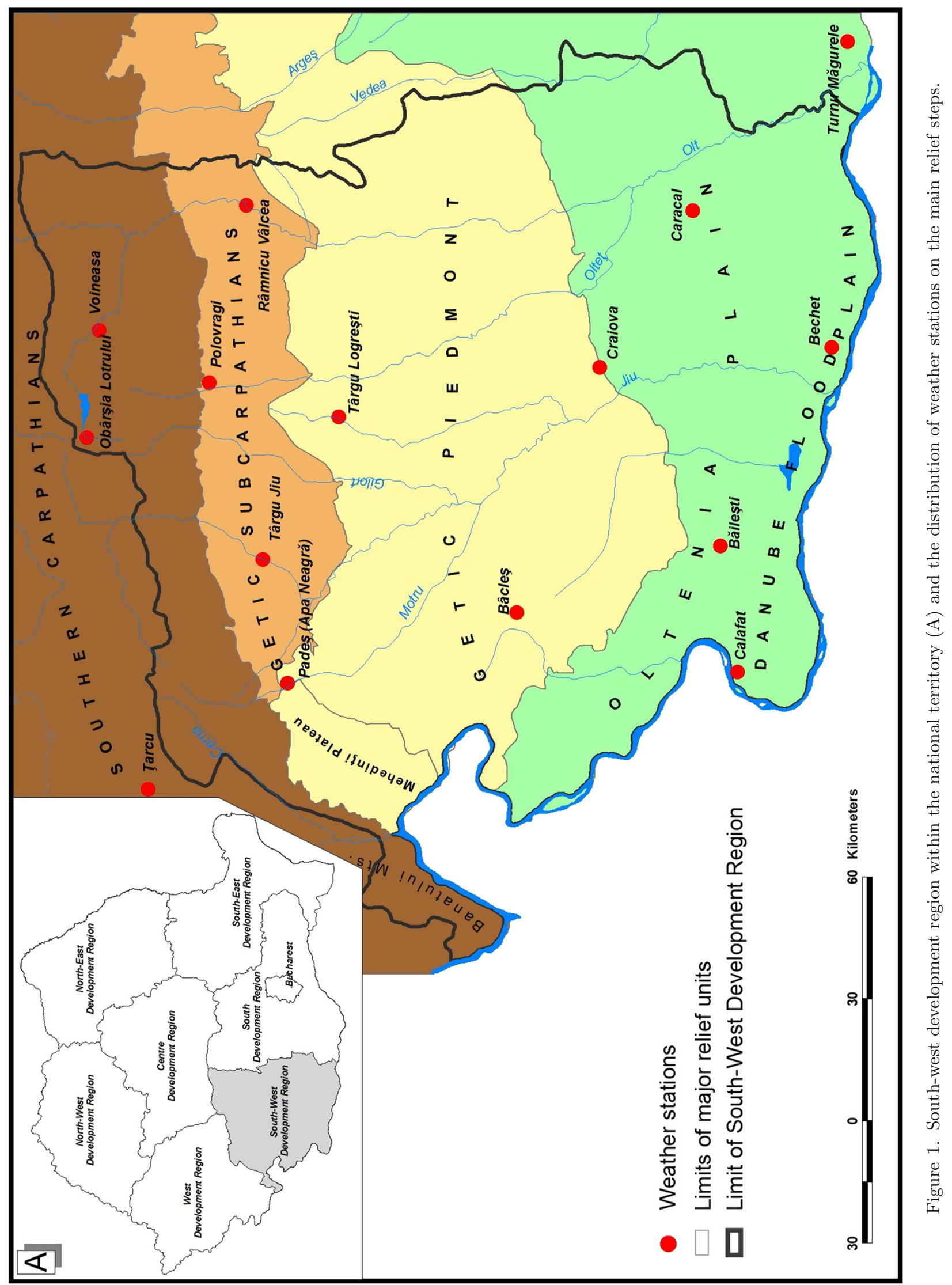



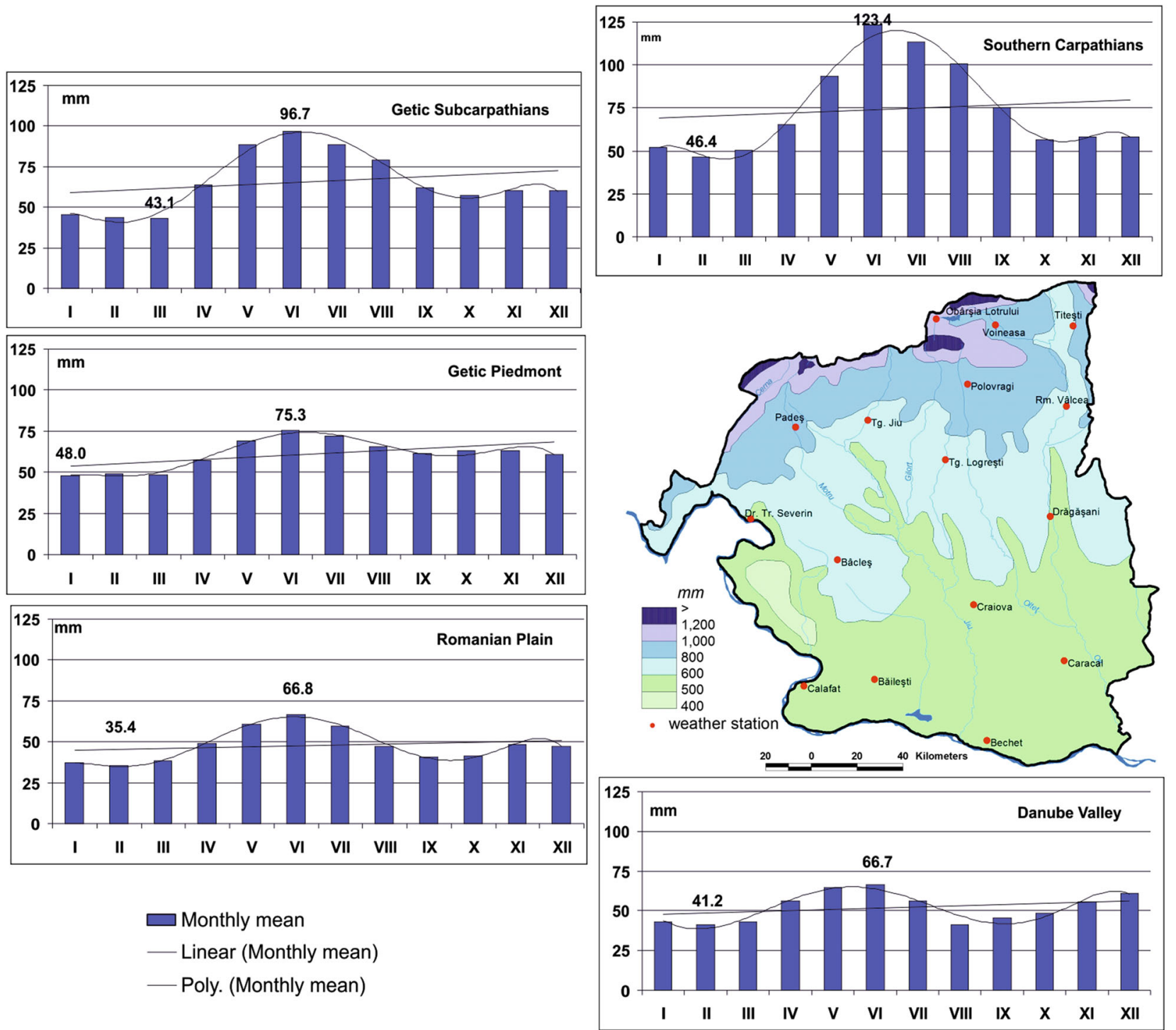

Figure 2. Mean annual and monthly multiannual precipitation amounts $(\mathrm{mm})$ on relief units totalised in the south-west development region.

while the Romanian plain does not exceed an average of $575 \mathrm{~mm}$ (figure 2).

The same spatial feature (decreasing from north to south) is also noticed in the monthly distribution of this parameter. For the mountain, hilly and plateau relief units, the wettest period is May-August with an average value of over $75 \mathrm{~mm} /$ month and a maximum quantity of $123.4 \mathrm{~mm}$. The plain and floodplain relief units, strongly influenced by the Mediterranean climate, include, in addition to the foremost maximum rainfall (May-July), a second pluvial peak (NovemberDecember) and a greater representation of intermonthly dry intervals. The lowest mean monthly amounts are totalised during wintertime, with values between $46 \mathrm{~mm}$ in the Southern Carpathians and $35.4 \mathrm{~mm}$ in the Romanian plain. The evolution trends in the multiannual mean monthly values slightly increase in all relief units, more prominent in the mountain and hilly regions.

The rainfall amounts cumulated in $24 \mathrm{hr}$, usually fallen during the warm semester of the year, genetically overlap the frontal and thermo-convective processes of the Azoric and Mediterranean circulations, thus reaching the highest values. At small and medium altitudes of the hilly, plain and floodplain relief forms, the highest rainfall amounts in diurnal regime are recorded in the summer months (July and August), followed by the autumn, and the spring months (especially May). In the mountain area, the heavy snowfalls during 


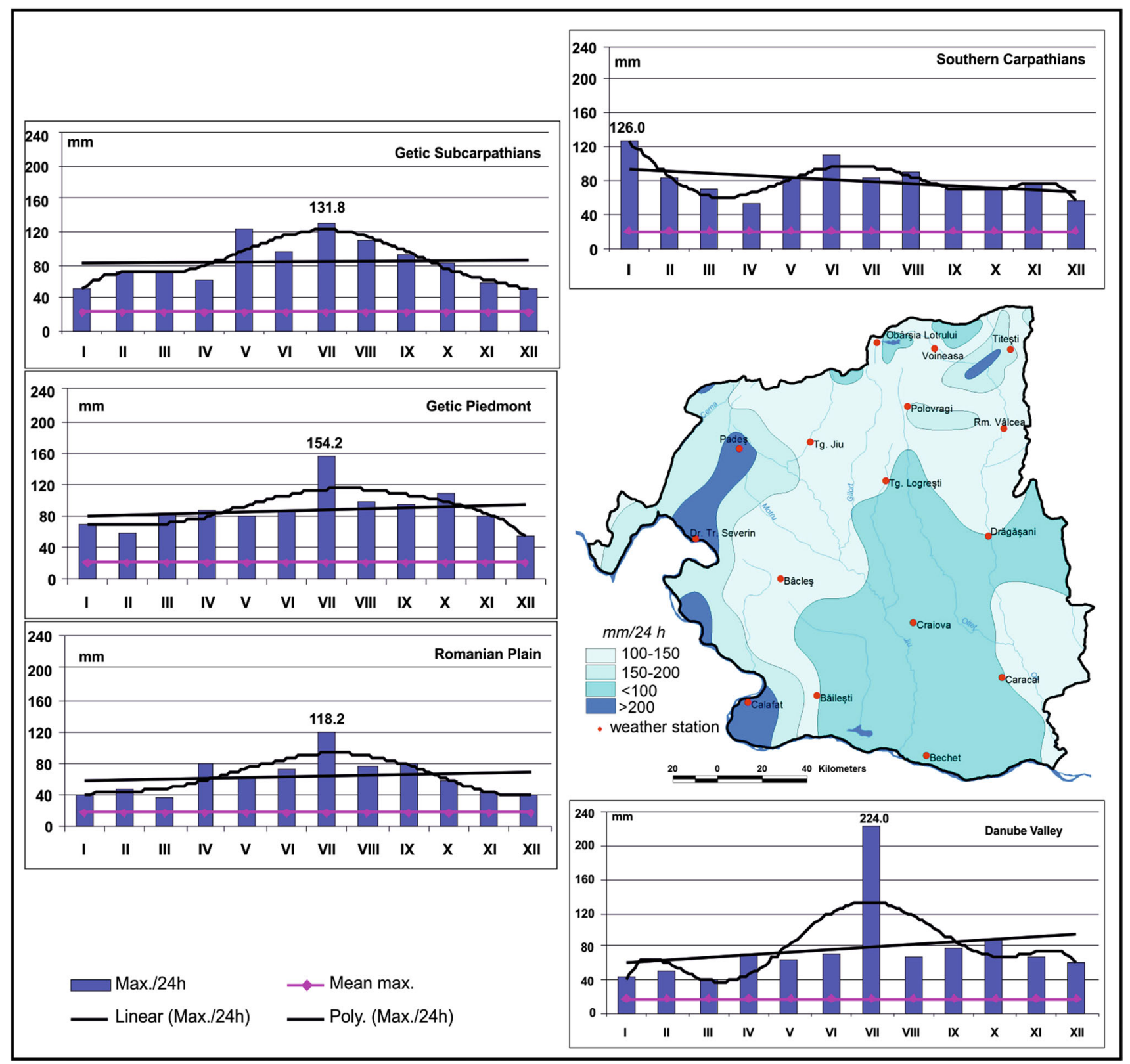

Figure 3. Absolute maximum precipitation amounts/24 hr, their monthly average and maximum values (1961-2010) on relief units.

winter marked the highest diurnal rainfall amounts in January (126.0 mm/January 2, 1966 at Vf. Tarcu weather station) (figure 3).

Generally, the highest precipitation amounts were registered in the floodplain area $(224.0 \mathrm{~mm} /$ July 12, 1999 at Drobeta Turnu Severin weather station) (table 4). These values exceeded the average monthly values, and in some cases, even come near the annual amounts registered in dry years. The evolution trend of the maximum rainfall/ 24 hr varies from one relief unit to another: decreasing in the mountain area and in the rest of the relief units.
One of the most significant examples of precipitation fallen in short intervals with a large coverage in the south-west development region is the heavy rainfall occurred during the July 1-3, 2005 interval which has generated, from April until November, seven flood waves with disastrous effects. The rainfall amounts cumulated in 3 days in a row equalled, and even exceeded, the multiannual monthly mean value registered within the 19012010 interval (table 5) (Dumitraşcu and Dumitraşcu 2001; Dragotă 2006; Dumitraşcu 2006).

The western air circulation and the humid tropical air of Mediterranean origin over the study area, 
Table 4. Absolute maximum amounts of precipitation/24 $h$ (1886-2010).

\begin{tabular}{lcc}
\hline $\begin{array}{l}\text { Weather } \\
\text { station/post }\end{array}$ & $\begin{array}{c}\text { Pp max/24 hr } \\
(\mathrm{mm})\end{array}$ & $\begin{array}{c}\text { Occurrence } \\
\text { date }\end{array}$ \\
\hline Calafat & 194.0 & 06.04 .1940 \\
Celei & 140.5 & 07.12 .1999 \\
Ciuperceni & 348.9 & 06.16 .1925 \\
Corbu & 125.0 & 07.02 .2005 \\
Corbu Buzeşti & 164.0 & 07.02 .2005 \\
Drăgăneşti-Olt & 185.0 & 07.31 .1955 \\
Drobeta Turnu & 224.0 & 07.12 .1999 \\
Severin & & \\
Scorniceşti & 137.0 & 2.07 .2005 \\
Glogova & 147.0 & 12.07 .1999 \\
Halânga & 267.0 & 11.07 .1999 \\
Mărunţei & 143.0 & 02.07 .2005 \\
Padeş (Apa Neagră) & 154.2 & 30.07 .1969 \\
Potcoava & 191.5 & 02.07 .2005 \\
Râmnicu Vâlcea & 122.3 & 10.05 .1973 \\
Târgu Jiu & 132.0 & 16.07 .1998 \\
Văleni & 168.0 & 02.07 .2005 \\
\hline Processed after Dragotă & &
\end{tabular}

Processed after Dragotă (2006).

Table 5. Rainfall amounts registered between the 1st and the 3rd of July 2005.

\begin{tabular}{|c|c|c|c|c|c|}
\hline \multirow[b]{2}{*}{$\begin{array}{l}\text { Weather } \\
\text { station }\end{array}$} & \multicolumn{4}{|c|}{ Precipitation amounts $(\mathrm{mm}) /$ Registration date } & \multirow[b]{2}{*}{ Relief unit } \\
\hline & July 1, 2005 & July 2,2005 & July 3, 2005 & $\begin{array}{c}\text { Total } \\
(1-3 \text { July, 2005) }\end{array}$ & \\
\hline Runcu & 30.8 & 87.5 & 1.8 & 120.1 & \multirow[t]{3}{*}{ Southern Subcarpathians } \\
\hline Corbu Buzeşti & 3.0 & 164.0 & - & 167.0 & \\
\hline Rovinari & 66.2 & 93.1 & 2.8 & 162.1 & \\
\hline Potcoava & - & 191.5 & 2.9 & 194.4 & \multirow[t]{4}{*}{ Getic Piedmont } \\
\hline Corbu & 5.0 & 125.0 & 27.0 & 157.0 & \\
\hline Gropşani & 71.0 & 87.5 & 13.0 & 171.5 & \\
\hline Văleni & 1.0 & 168.0 & 4.9 & 173.9 ) & \\
\hline Mărunţei & 27.3 & 143.0 & 21.5 & 191.8 & \multirow{4}{*}{$\begin{array}{l}\text { Romanian Plain } \\
\text { (Oltenia Plain) }\end{array}$} \\
\hline Breasta & 55.0 & 75.0 & 26.0 & 156.0 & \\
\hline Slatina & 18.6 & 109.4 & 30.0 & 158.0 & \\
\hline Drăgăneşti-Olt & - & 109.9 & 18.1 & 128.0 ) & \\
\hline
\end{tabular}

Processed after Marinică (2006).

as well as the unequal heating of the terrestrial surface generate heavy rainfall, with a higher frequency during the spring and summer, triggering floods. From the point of view of the synoptic situations, in the study area, heavy rainfall frame into five main types acting differently throughout the analysed territory (table 6).

During summertime, type $\mathrm{V}$ of thermo-convective nature, is more frequent, especially in the southern parts. One significant sector where heavy rainfall are registered is that of the sand dunes at Ciuperceni-Desa-Calafat, where the underlying sand surface is rapidly heated and the frequency of unstable moist and tropical air is very high. In such situations, in plain areas, rainfall of a torrential character reached maximum intensities of over $4 \mathrm{~mm} / \mathrm{min}$. Similar high historical diurnal amounts were registered at Drobeta Turnu Severin $(224.0 \mathrm{~mm} / 12.07 .1999)$ and at Calafat (194.0 $\mathrm{mm} / 4.06 .1940)$.

Another region affected by heavy rainfall covers the Subcarpathian depression corridor of Oltenia, 
Table 6. The main rainfall types and their particular features.

\begin{tabular}{|c|c|c|}
\hline Type & Characteristics & Main areas \\
\hline I & Triggered by the Mediterranean cyclones & $\begin{array}{l}\text { Getic Subcarpathians and pied- } \\
\text { mont, Romanian plain, Danube } \\
\text { valley }\end{array}$ \\
\hline II & $\begin{array}{l}\text { Triggered by the cyclones centred in the Pan- } \\
\text { nonia plain }\end{array}$ & $\begin{array}{l}\text { Southern Carpathians, } \\
\text { Getic Subcarpathians and piedmont }\end{array}$ \\
\hline III & $\begin{array}{l}\text { Inside the depression corridor formed between } \\
\text { an Icelandic anti-cyclone and a cyclone from the } \\
\text { eastern basin of the Mediterranean Sea }\end{array}$ & The entire area \\
\hline IV & Generated at the limits of an anti-cyclonic field & The entire area \\
\hline $\mathrm{V}$ & Of a thermo-convective nature & Danube valley, Romanian plain \\
\hline
\end{tabular}

Processed and adapted after Milea et al. (1974).

Table 7. Selected maximum quantity of heavy rainfall in the south-west development region.

\begin{tabular}{llccc}
\hline $\begin{array}{l}\text { Meteorological } \\
\text { station }\end{array}$ & Date of occurrence & $\begin{array}{c}\text { Intensity } \\
(\mathrm{mm} / \mathrm{min})\end{array}$ & $\begin{array}{c}\text { Duration } \\
(\mathrm{min})\end{array}$ & $\begin{array}{c}\text { Total quantity of } \\
\text { water/interval }(\mathrm{mm})\end{array}$ \\
\hline Tismana & 4 May, 1939 & 1.00 & 35 & 35.0 \\
Târgu Jiu & 30 July, 1941 & 5.60 & 6 & 33.6 \\
Strehaia & 20 April, 1940 & 1.94 & 7 & 13.6 \\
Ciupercenii Vechi & 28 June, 1945 & 6.15 & 2 & 12.3 \\
Calafat & 29 July, 1963 & 2.20 & 29 & 63.8 \\
Bechet & 20 August, 1975 & 9.00 & 1 & 9.0
\end{tabular}

Processed after Clima României 1961-1962, Sandu et al. (2008), Dragotă (2006) and Marinică (2006).

where, under the influence of the Mediterranean cyclones with south-western-north-eastern direction, the orographic barrier of the Southern Carpathians has a decisive role in the increased rain intensity.

Under these conditions, the rainfall intensities reaching up to $9 \mathrm{~mm} / \mathrm{min}$ were noticed (table 7 ). As the altitude increases, the pluvial intensity drops under $3 \mathrm{~mm} / \mathrm{min}$ due to the increase in air humidity, which suppress air temperature values, thus preventing thermal convection. The multiannual monthly rainfall frequency on specific thresholds (5, 10 and $20 \mathrm{~mm}$ ) sharply delineates the Carpathian and Subcarpathian area, with the highest values, of the plain and floodplain areas, with the smallest rates. On an yearly basis, for the 5 $\mathrm{mm}$ and $10 \mathrm{~mm}$ thresholds, the March-October interval marks the season of the year most affected by such amounts, while the upper threshold (20 $\mathrm{mm}$ ) is restricted to the May-September period (figure 4).

The increased erosive potential of high-quantity or high-intensity rainfalls generally covers the May-August interval also known as "critical ero- sion season' when heavy rainfall with a probability of occurrence $>50 \%$ occur (Dragotă 2006).

The damaging aspects of the heavy rainfalls depend on the intensity, duration, water quantity fallen and particular features of the active surface: lithology, presence/absence of the vegetation cover, slope, and occurrence period (after long periods of drought when the soil is extremely dry and has a low cohesion; after a rainy period; before or after snowmelt, when soil is over-moist). In such conditions, the heavy precipitation amounts trigger floods and accelerated erosion processes such as slope failure or landslides. Having a negative effect on the environment, they are likely to affect crops, infrastructure (roads, bridges, railways, sewage pipes, water and gas supply), etc.

\subsection{Assessment of the pluvial aggressiveness using relevant erodibility indices}

The pluvial aggressiveness. Among the main components of the pluvial regime, the analysed rainfall parameters (rain showers, hails and pluvial intensities) have the strongest impact on the environment, 


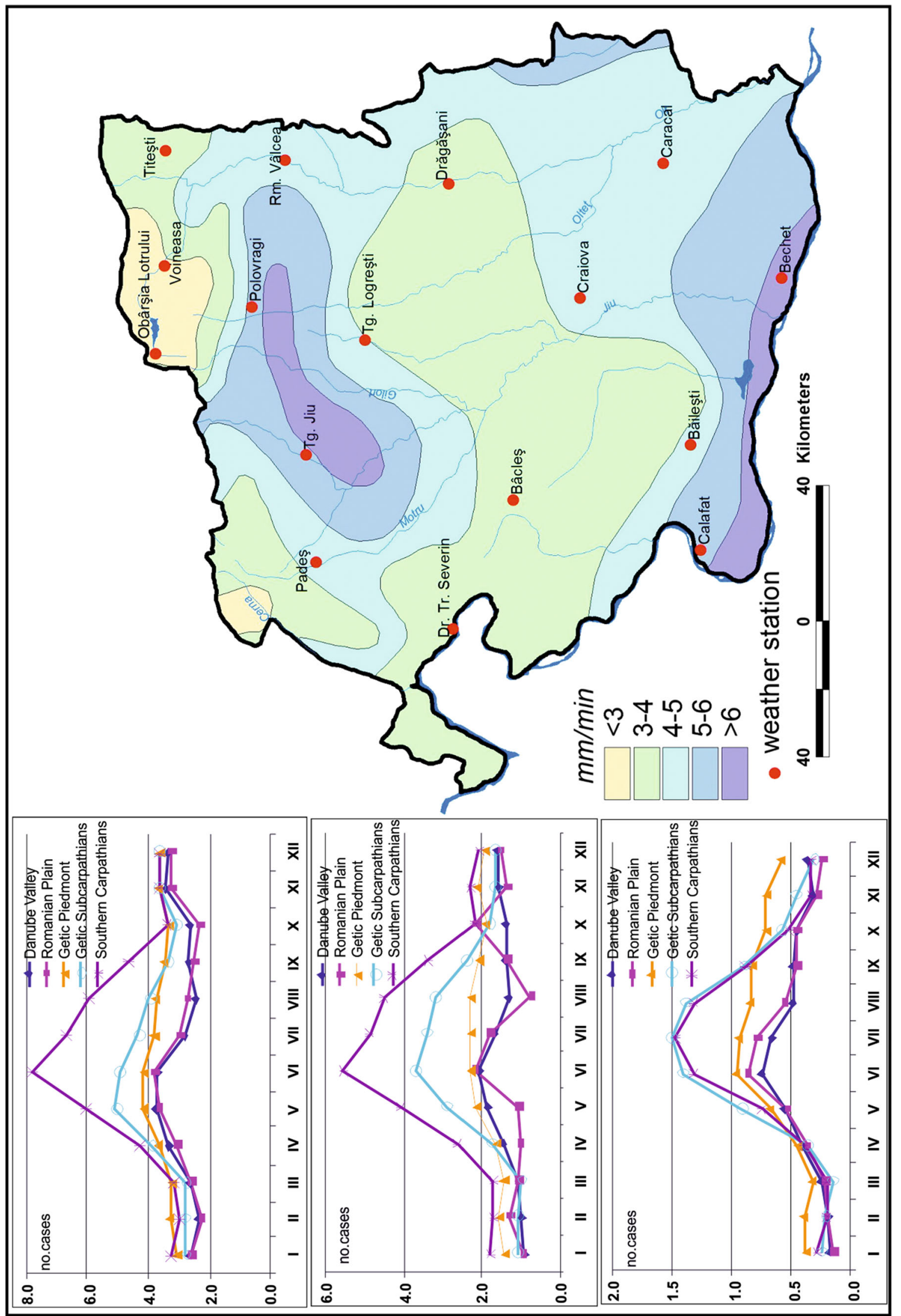

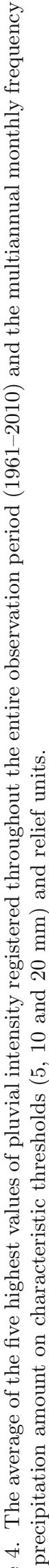




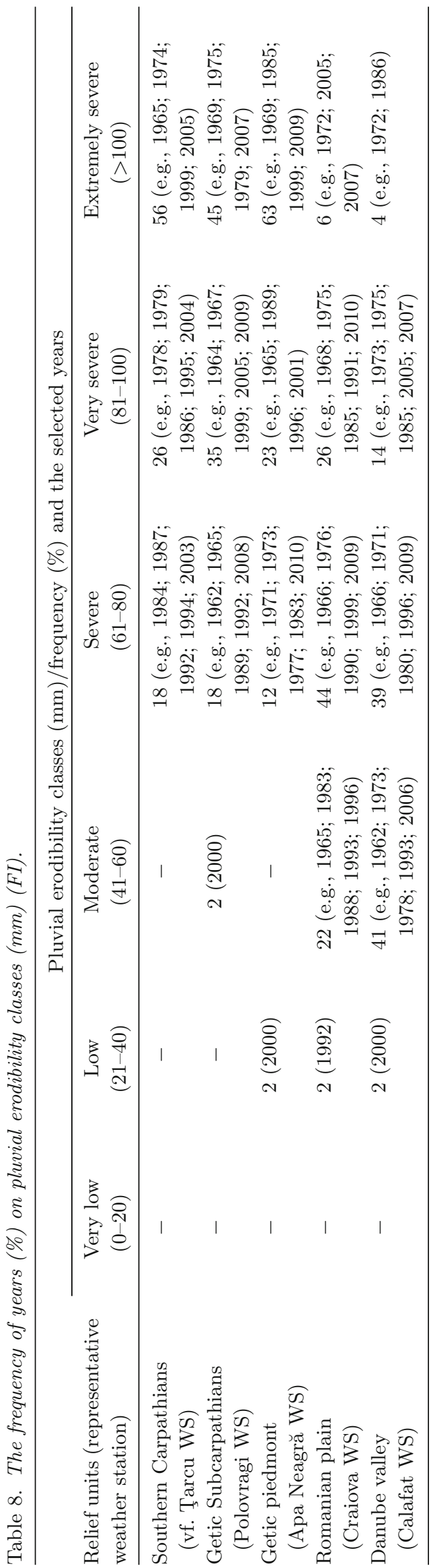

thus being taken into consideration for the assessment of some specific erodibility indices.

Thus, surface erosion was assessed based on FI and MFI (Fournier 1960; Arnoldus 1980), while linear and slope erosion based on Angot index.

The pluvial aggressiveness index registers extremely severe values in the Getic piedmont with $63 \%$ of the analysed years (Apa Neagră weather station), followed by the Southern Carpathians with $56 \%$ (vf. Tarcu weather station) and the Getic Subcarpathians with $45 \%$ (Polovragi weather station). Here, the lower erodibility classes are rather insignificantly addressed.

In the Danube valley and Romanian plain (Calafat and Craiova weather stations), the frequency of years which fall in the moderate (up to $41 \%$ ), severe (up to $44 \%$ ) and very severe (up to $26 \%$ ) value classes reaches the highest percentage in 1966, 1985, 2005 and 2009, while the very low and low class values (under $2 \%$ ) and the extreme severe class $(<6 \%)$ are particularly rare. Generally, in the study area, the FI values higher than 100 mm were mostly cumulated in 1969, 1972, 1999 and 2007 (table 8; figure 5).

The MFI comes to complete the information on pluvial aggressiveness on monthly multiannual basis. Therefore, according to the established pluvial aggressiveness classes, the mean multiannual values reveal a prevalence of the low and moderate classes (the Southern Carpathians and the Subcarpathians and the Getic piedmont) with an additional very low class values in the Getic Subcarpathians. Low and very low aggressiveness values are characteristic for the areas located in the Danube valley and the Romanian plain. Very severe class values are poorly displayed both in the Getic piedmont (6\%) and the Southern Carpathians and the Getic Subcarpathians (2\%) (table 9; figure 5).

The susceptibility of the south west development region to erosion processes was also estimated using Angot pluvial index $(K)$, which was computed for selected weather stations for each relief unit. The unleashing of these erosion processes has as key triggering factor, either heavy precipitation fallen on long periods or their high intensity, both favouring torrential processes and flood events. The used database covers the warm semester of the year when positive Angot index values are registered. The most favourable conditions for the occurrence of erosion processes, from pluvial point of view, are reached within the April-September interval, when the highest rainfall amounts are also recorded (figure 6). 


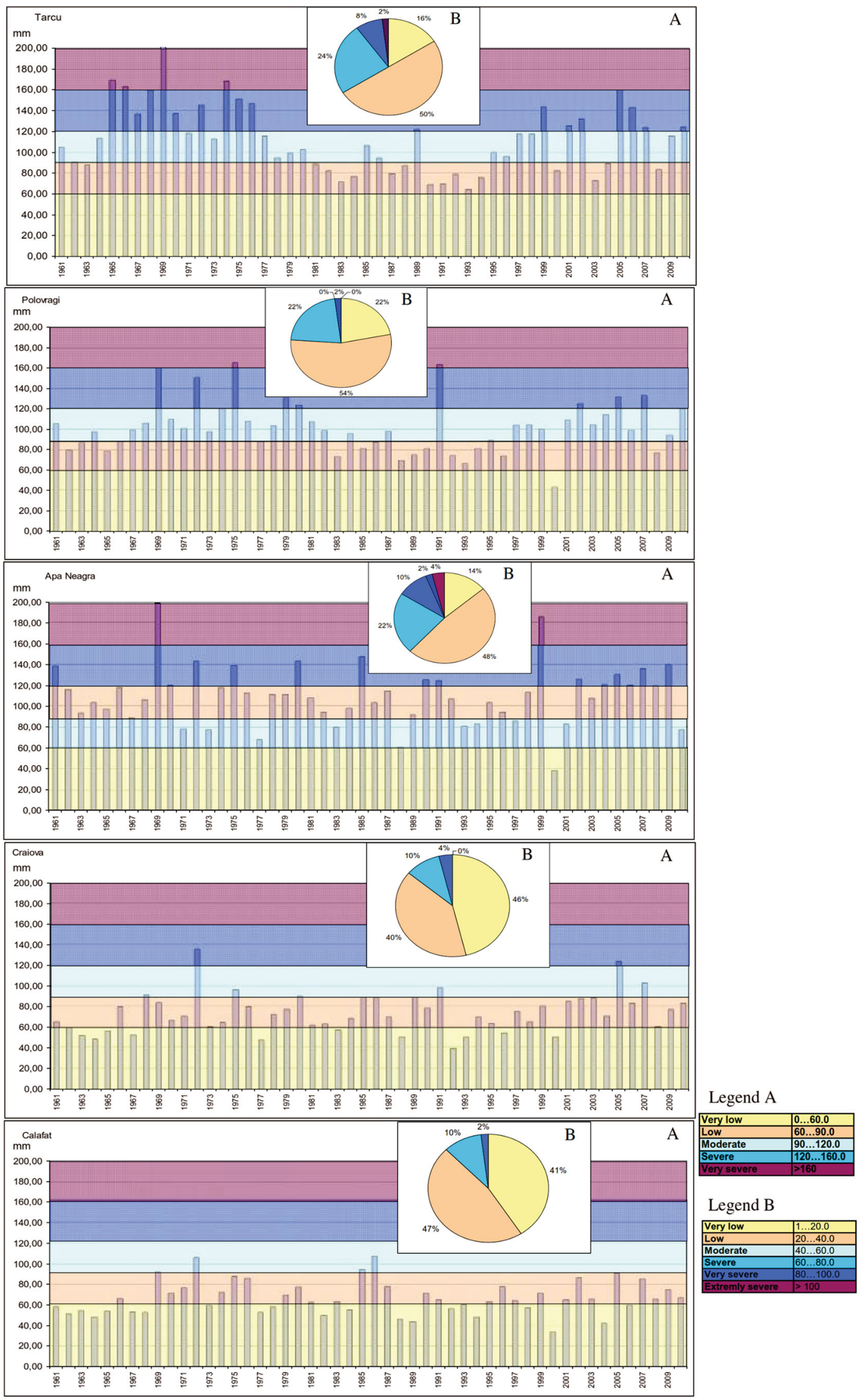

Figure 5. Pluvial erodibility index - FI (A) and MFI (B) during the warm semester of the year at selected weather stations in the south-west development region. 
Table 9. The frequency of years (\%) on pluvial erodibility classes (mm) (MFI).

\begin{tabular}{lccccc}
\hline & \multicolumn{5}{c}{ Pluvial erodibility classes (mm)/frequency } \\
\cline { 2 - 6 } $\begin{array}{l}\text { Relief units (representa- } \\
\text { tive weather station) }\end{array}$ & $\begin{array}{c}\text { Very low } \\
(0-60)\end{array}$ & $\begin{array}{c}\text { Low } \\
(61-90)\end{array}$ & $\begin{array}{c}\text { Moderate } \\
(91-120)\end{array}$ & $\begin{array}{c}\text { Severe } \\
(121-160)\end{array}$ & $\begin{array}{c}\text { Very severe } \\
(>160)\end{array}$ \\
\hline $\begin{array}{c}\text { Southern Carpathians } \\
\quad \text { vf. Ţarcu WS) }\end{array}$ & 16 & 50 & 24 & 8 & 2 \\
$\begin{array}{c}\text { Getic Subcarpathians } \\
\text { (Polovragi WS) }\end{array}$ & 22 & 54 & 22 & 0 & 2 \\
$\begin{array}{c}\text { Getic piedmont (Apa } \\
\text { Neagră WS) }\end{array}$ & 14 & 48 & 22 & 10 & 6 \\
$\begin{array}{c}\text { Romanian plain } \\
\text { (Craiova WS) }\end{array}$ & 46 & 40 & 10 & 4 & 0 \\
$\begin{array}{c}\text { Danube valley (Calafat } \\
\text { WS })\end{array}$ & 41 & 47 & 10 & 2 & 0 \\
\hline
\end{tabular}

Table 10. Monthly susceptibility of Angot pluvial index classes (1961-2010).

\begin{tabular}{|c|c|c|c|c|c|c|}
\hline \multirow{2}{*}{$\begin{array}{l}\text { Susceptibility class/Angot } \\
\text { index values }\end{array}$} & \multicolumn{6}{|c|}{ Month (\%) } \\
\hline & $\mathrm{A}$ & $\mathrm{M}$ & $\mathrm{J}$ & $\mathrm{J}$ & A & $\mathrm{S}$ \\
\hline \multicolumn{7}{|c|}{ Southern Carpathians (Vf. Ţarcu weather station) } \\
\hline Very low $(<1.0)$ & 22 & 4 & 0 & 0 & 6 & 20 \\
\hline Low $(1.0-1.5)$ & 18 & 16 & 4 & 12 & 6 & 6 \\
\hline Moderate (1.6-2.0) & 4 & 8 & 2 & 10 & 14 & 10 \\
\hline Severe $(2.1-2.5)$ & 18 & 14 & 4 & 4 & 16 & 16 \\
\hline Very severe $(>2.5)$ & 38 & 58 & 90 & 74 & 58 & 48 \\
\hline \multicolumn{7}{|c|}{ Getic Subcarpathians (Polovragi weather station) } \\
\hline Very low $(<1.0)$ & 6 & 2 & 4 & 10 & 10 & 34 \\
\hline Low $(1.0-1.5)$ & 10 & 2 & 8 & 8 & 20 & 10 \\
\hline Moderate $(1.6-2.0)$ & 16 & 14 & 14 & 12 & 10 & 4 \\
\hline Severe $(2.1-2.5)$ & 26 & 22 & 10 & 16 & 10 & 12 \\
\hline Very severe $(>2.5)$ & 42 & 60 & 64 & 54 & 50 & 40 \\
\hline \multicolumn{7}{|c|}{ Getic piedmont (Apa Neagră weather station) } \\
\hline Very low $(<1.0)$ & 8 & 10 & 6 & 16 & 28 & 24 \\
\hline Low $(1.0-1.5)$ & 16 & 4 & 14 & 18 & 22 & 20 \\
\hline Moderate $(1.6-2.0)$ & 14 & 12 & 0 & 10 & 14 & 6 \\
\hline Severe $(2.1-2.5)$ & 14 & 14 & 14 & 8 & 8 & 8 \\
\hline Very severe $(>2.5)$ & 48 & 60 & 66 & 48 & 28 & 42 \\
\hline \multicolumn{7}{|c|}{ Romanian Plain (Craiova weather station) } \\
\hline Very low $(<1.0)$ & 18 & 14 & 18 & 24 & 42 & 46 \\
\hline Low $(1.0-1.5)$ & 34 & 24 & 10 & 20 & 30 & 16 \\
\hline Moderate $(1.6-2.0)$ & 18 & 14 & 18 & 14 & 5 & 12 \\
\hline Severe $(2.1-2.5)$ & 12 & 22 & 10 & 18 & 5 & 8 \\
\hline Very severe $(>2.5)$ & 18 & 26 & 44 & 24 & 18 & 18 \\
\hline \multicolumn{7}{|c|}{ Danube valley (Calafat weather station) } \\
\hline Very low $(<1.0)$ & 25 & 18 & 21 & 42 & 58 & 51 \\
\hline Low $(1.0-1.5)$ & 27 & 35 & 31 & 20 & 16 & 17 \\
\hline Moderate (1.6-2.0) & 22 & 14 & 6 & 10 & 6 & 8 \\
\hline Severe $(2.1-2.5)$ & 12 & 10 & 10 & 8 & 6 & 10 \\
\hline Very severe $(>2.5)$ & 14 & 23 & 32 & 20 & 14 & 14 \\
\hline
\end{tabular}

A: April, M: May, J: June, J: July, A: August, S: September. 

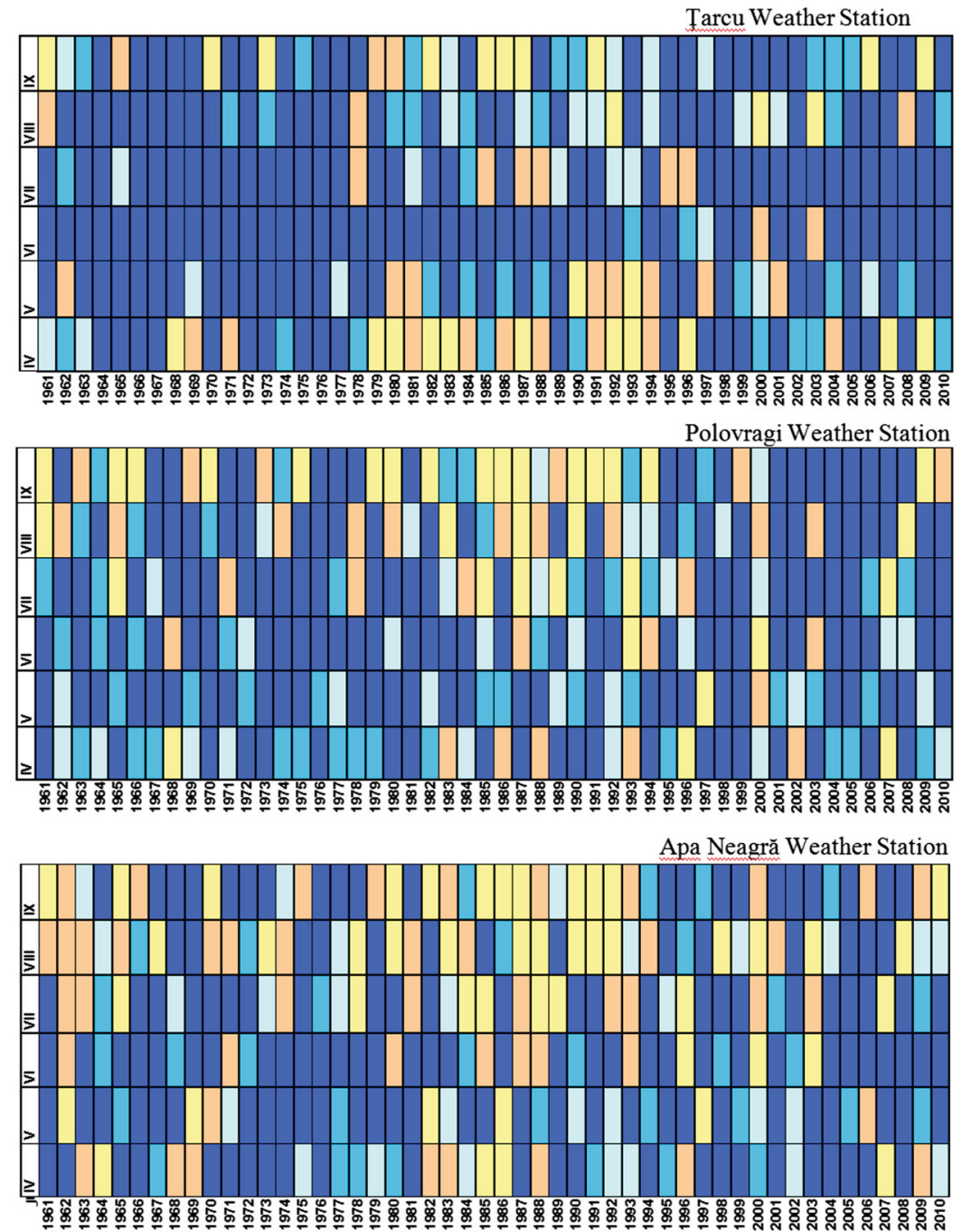

Craiova Weather Station
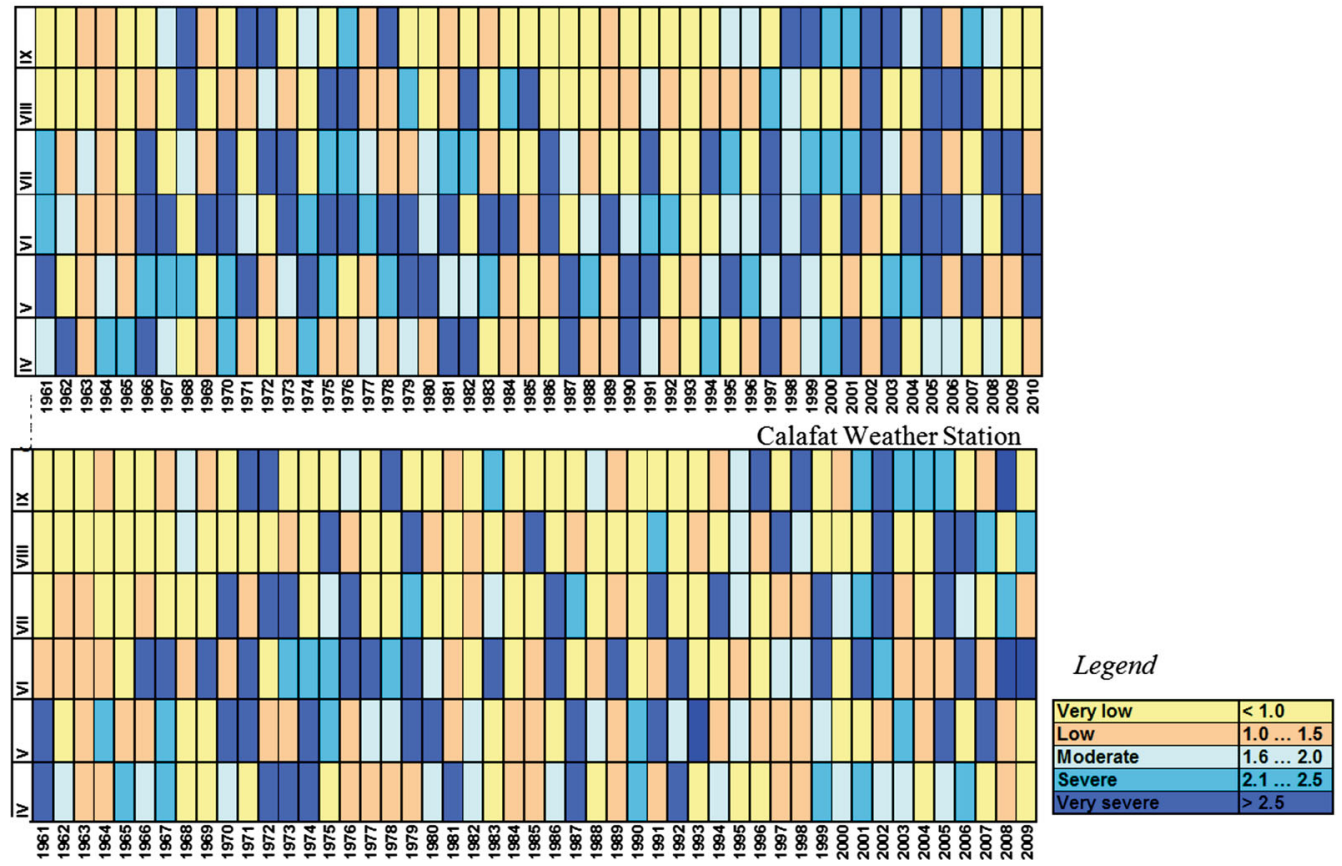

Figure 6. Mean multiannual values of Angot Pluvial Index during the warm semester of the year at selected weather stations in the south-west development region. 
According to Angot index, in the mountain area the highest susceptibility is registered during the June--July interval with over $74 \%$ of cases, of which a high representativeness of the very severe class was registered within the 1961-1977 and 1998-2010 intervals (Tarcu weather station). As the altitude drops in the Getic Subcarpathians, severe and very severe class values are approximately equally distributed on a multiannual basis.

In September, over the 1985-1993 interval, very low and low value classes (Polovragi weather station) are interspersed. In the Getic piedmont, all susceptibility classes are more uniformly distributed in August and September, while in the months of May and June very severe and severe classes prevail, with over $60 \%$ (Apa Neagra weather station). In the Romanian plain (Craiova weather station) and the Danube valley (Calafat weather station) very low and low classes overcome, especially in April, August and September (table 10; figure 6).

\section{Conclusions}

The south-west development region displays a moderate to excessive pluvial regime from the plain regions to the hilly and mountain sectors. The pluvial aggressiveness is defined by the precipitation amounts considered for the computation of the selected indices (Fournier, Fournier Modified and Angot). Due to relief diversity and configuration, declivity and soil types, which allow water percolation, susceptibility classes register different values. Thus, at low altitudes, namely within the Danube valley and Oltenia plain (western sector of the Romanian plain), there predominate very low, low and moderate erodability classes, while at higher altitudes erodability is severe and extremely severe. According to MFI Index, the highest percents of the severe and extremely severe erodibility classes are registered in the hilly sector of the analysed region (Getic piedmont), 10 respectively 6\%, where erosion is triggered by both rainfalls with high intensity, especially in summer, and friable exposed soils.

Angot pluvial index $(K)$, which was calculated for the warm semester of the year, emphasized that the very severe susceptibility class displays the highest percents in different months, if the altitude of the relief forms are considered. In the Carpathians, June and July registered the highest percents -90 , respectively $74 \%$. In the hilly area (Getic Subcarpathians and piedmont), the months with the greatest percents are May and June (between 60 and 66\%), while in low areas, the same two months display lower values (22$44 \%$ ). Consequently, the relief particularities and the interaction with the general atmospheric circulation in the study area greatly contributes to the spatial pattern of rainfall erodability potential in terms of intensity, frequency and spatial distribution of the triggered erosion processes.

Heavy precipitation trigger destructive floods and accelerated erosion processes such as flash floods in small river catchments (the Southern Carpathians and the Getic Subcarpathians) and slope failure or landslides, especially in the Getic piedmont and the Getic Subcarpathians. During periods with excess humidity, heavy rainfall and the associated meteorological phenomena (e.g., rain showers, hailstorms) are likely to produce serious damaging effects on agricultural crops and pastures determining land use/land cover changes and soil degradation, mostly in the Romanian plain and the Danube valley. Generally, they would cause significant damage to the transport and technical-edilitary infrastructure (e.g., bridges, railways, sewage pipes, and water and gas supply) throughout the entire study area.

\section{Acknowledgements}

The study was conducted in the framework of the research project: "Assessment of natural and technological hazards at national, regional and local levels" of the Institute of Geography, Romanian Academy, and the research theme of the Faculty of Geography, Spiru Haret University "Natural and technological hazards in urban ecosystems of the South West Development Region of Romania". The authors would like to thank the anonymous reviewers for their highly constructive comments and suggestions that helped improve this paper. All authors equally contributed to all stages of the article, i.e., data acquisition, processing, analysis and interpretation, and study conceptualization.

\section{References}

Angulo-Martinez M and Begueria S 2009 Estimating rainfall erosivity from daily precipitation records: A comparison among methods using data from the Ebro Basin (NE Spain); J. Hydrol. 379(1-2) 111-121. 
Arnoldus H M J 1980 An approximation of the rainfall factor in the universal soil loss equation; In: Assessment of Erosion (eds) De Boodt M and Gabriels D, Wiley, Chichester, pp. 127-132.

Bălteanu D 1997 Geomorphological hazards of Romania; In: Geomorphological hazards of Europe (eds) Embleton $\mathrm{C}$ and Embleton-Hamann Ch, Elsevier, Amsterdam, pp. 409-427.

Bogdan O and Niculescu E 2006 The Climate; In: Romania. Space, Society, Environment (eds) Bălteanu D, Badea L, Buza M, Niculescu Gh, Popescu C and Dumitraşcu M, The Publishing House of the Romanian Academy, Bucharest, pp. 82-96.

Busuioc A, Caian M, Cheval S, Bojariu R, Boroneant C, Baciu, M and Dumitrescu Al 2010 Variability and climate change in Romania, Editura PRO Universitaria, Bucureşti, 226p (in Romanian).

Busuioc A, Dobrinescu A, Birsan MV, Dumitrescu A and Orzan A 2015 Spatial and temporal variability of climate extremes in Romania and associated large-scale mechanisms; Int. J. Climatol. 35(7) 1278-1300, doi: 10.1002/ joc. 4054 .

Capra A, Porto P and La Spada C 2015 Long-term variation of rainfall erosivity in Calabria (southern Italy); Theoret. Appl. Climatol., 1-18, doi: 10.1007/s00704-015-1697-2.

Chendeş V, Bălteanu D, Micu D, Sima M, Ion B, Grigorescu I, Persu M and Dragotă C S 2015 A database design of major past flood events in Romania from national and international inventories; Air and Water Components of the Environment, pp. 25-32.

Costea M 2012 Using the Fournier Indices in Estimating Rainfall Erosivity. Case Study - The Secaşul Mare Basin; Aerul si Apa. Componente ale Mediului, pp. 313320.

Clima României 1961-1962 The Climate of Romania; Institutul Meteorologic, Bucharest (in Romanian).

De Jong S M, Brouwer L C and Riezebos H Th 1998 Erosion hazard assessment in the Peyne catchment, France; Working paper DeMon-2 Project. Dept. Physical Geography, Utrecht University.

Dragotă CS 2006 Excess precipitation in Romania; The Publishing House of the Romanian Academy, Bucharest, 176p (in Romanian).

Dragotă C S, Micu M and Micu D 2008 The relevance of pluvial regime for landslides genesis and evolution. Casestudy: Muscel basin (Buzău Subcarpathians), Romania; Present Environment and Sustainable Development $\mathbf{2}$ 253-269.

Dragotă C S, Grigorescu I, Dumitraşcu M and Kucsicsa Gh 2014 Pluvial hazards assessment in the Danube floodplain. The Calafat-Turnu Măgurele sector; Problems of Geography 1-2 100-114, http://www.niggg.bas.bg/wp-content/ uploads/2014/07/12_2014.pdf

Dumitraşcu M 2006 Landscape changes in the Oltenia Plain, The Publishing House of the Romanian Academy, Bucharest, 239p (in Romanian).

Dumitraşcu M, Dumitraşcu C 2001 The vulnerability of the urban ecosystems to natural risks; Comunicări de Geografie IV 227-232 (in Romanian).

Elagib N A 2010 Changing rainfall, seasonality and erosivity in the hyper-arid zone of Sudan; Land Degrad. Dev. 22(6) 505-512.
Elbasit A M, Huang J, Ojha C S P, Yasud H and Eltayeb O A 2013 Spatiotemporal changes of rainfall erosivity in Loess Plateau, China; ISRN Soil Science, http://www.hindawi. com/journals/isrn/2013/256352/.

Fournier F 1960 Climate et erosion, la relation entre erosion du sol par l'eau de precipitation atmospherique; Presses Universitaries de Frame, Paris.

Grecu F, Ghiţă C and Cîrciumaru E 2011 Land vulnerability to geomorphological hazard induced by pluviometric criteria (Romanian plain); Revista de Geomorfologie 13 59-66.

Ion-Bordei N 2008 Meteoclimate phenomena induced by the Carpathian Mountains configurations in the Romanian plain; Romanian Academy edn, 174p (in Romanian).

Marinică I 2006 Risk climatic phenomena in Oltenia; Autograf MJM, Printing House Craiova, 386p (in Romanian).

Meshesha T D, Tsunekawa A, Tsubo M, Haregeweyn N and Adgo E 2015 Evaluating spatial and temporal variations of rainfall erosivity: Case of central rift alley of Ethiopia; Theoret. Appl. Climatol. 119 515-522.

Milea E, Bacinschi D and Doneaud A 1974 The meteorological study of the high waters of October 4-12, 1972 in southern Romania; Culegere de Lucrări de Meteorologie, pp. 59-84 (in Romanian).

Mohtar Z A, Yahaya A S and Ahmad F 2015 Rainfall erosivity estimation for northern and southern peninsular Malaysia using Fourneir indices; Procedia Engineering $125179-184$.

Morgan R P C, Quinton J N, Smith R E, Govers G, Poesen J W A, Auerswald K, Chisci G, Torri D, Styczen M E and Folly A J V 1998 The European soil erosion model (EUROSEM): Documentation and user guide, Silsoe College, Cranfield University.

Munka C, Cruz G and Caffera R M 2008 Long term variation in rainfall erosivity in Uruguay: A preliminary Fournier approach; Geol. J. 70(4) 257-262.

Oduro-Afriyie K 1996 Rainfall erosivity map for Ghana; Geoderma 74(1-2) 161-166.

Oncia S and Copacean L 2015 Vulnerability to surface erosion due to rainfalls and relief, Res. J. Agr. Sci. 47(1) 138-147.

Panagos P, Borrelli P, Poesen J, Ballabio C, Lugato E, Meusburger K, Montanarella L and Alewell C 2015 The new assessment of soil loss by water erosion in Europe; Environ. Sci. Policy $\mathbf{5 4}$ 438-447.

Peel M C, Finlayson B L and McMahon T A 2007 Updated world map of the Koppen-Geiger climate classification; Hydrol. Earth Syst. Sci. 11(5) 1633-1644.

Renard K G, Foster G R, Weesies G A, McCool D K and Yoder D C 1997 Predicting Soil Erosion by Water: A Guide to Conservation Planning with the Revised Universal Soil Loss Equation (RUSLE) (Agricultural Handbook 703); US Department of Agriculture, Washington DC, 404p.

Rusu T, Moraru P, Coste C, Cacovean H, Chetan F and Chetan C 2014 Impact of climate change on climatic indicators in Transylvanian plain, Romania; J. Food Agr. Environ. 12(1) 469-473.

Sandu I, Pescaru V, Poiană I, Geicu A, Cândea I and Ţâştea D (eds) 2008 The Climate of Romania; The Romanian Academy Publishing House, Bucharest, 365p (in Romanian). 
Sandu I, Mateescu E and Vătămanu V 2010 Climate change in Romania and the effects on agriculture; SITECH Printing House, Craiova, 406p (in Romanian).

Stânga I C 2011 Climate agressiveness and rainfall erosivity; Riscuri şi Catastrofe X 9(2) 21-32.

Ştefănescu V 2013 Decision support system based on the history of flood and flash flood events in Romania; Nat. Hazards 65 2331-2352, doi: 10.1007/s11069-012-0479-8.

Ştefănescu V, Ştefan S and Georgescu F 2014 Spatial distribution of heavy precipitation events in Romania between 1980 and 2009; Meteorol. Appl. 21 684-694, doi: 10.1002/ met.1391.

Corresponding editor: Subimal GHOSH
Wischmeier W and Smith D 1978 Predicting Rainfall Erosion Losses: A Guide to Conservation Planning; Agricultural Handbook No. 537, U.S. Department of Agriculture, Washington DC, USA.

World Health Organization 2013 Floods in the WHO European Region: Health effects and their prevention (eds) Menne B and Murray V, Public Health England, 146p.

Yue J B, Shi H Z and Fang F N 2014 Evaluation of rainfall erosivity and its temporal variation in the Yanhe River catchment of the Chinese Loess Plateau; Nat. Hazards 74(2) 585-602. 